\title{
Growth and Water Use Characteristics of Six Eastern North American Oak (Quercus) Species and the Implications for Urban Forestry
}

\author{
Daniel K. Struve, Petra Sternberg, Nick Drunasky, Kurt Bresko, and Rico Gonzalez
}

\begin{abstract}
Seedling growth and water use of six North American oak species were studied in a series of four experiments to determine inter- and intraspecies water use characteristics. Xeric-site adapted species (chestnut oak, Q. prinus [L.] and black oak, Q. velutina [Lamb.]) had slower growth (height and dry weight accumulation and lower shoot:root ratios) than mesic-site adapted species (bur oak, Quercus macrocarpus [Michx.]; pin oak, Q. palustris [Muenchh.], northern red oak, Q. rubra [L]; and Shumard oak, Q. shumardii [Buckl.]). Principal component analysis (a statistical technique used to identify correlated variables) using 11 variables found that seedling water use loaded positively with seedling growth factors (taller seedlings tended to have higher dry weights and greater leaf and root areas and used more water than shorter seedlings, which tended to have lower dry weights, smaller leaf, and root areas) in the first principal component. However, in the third experiment, seedling growth factors loaded negatively with seedling water use for $Q$. prinus. Tall $Q$. prinus seedlings tended to use less water than short seedlings. However, other measures of water use $\left(\mathrm{g}\right.$ water $\mathrm{cm}^{-1}$ height and $\mathrm{cm}^{-2}$ leaf and root area) loaded negatively on the first principal component. Correlations between seedling heights and seedling waters use were significant and positive, but great within-species and within half-sib family differences in height-adjusted water use ( $\mathrm{g}$ water $\mathrm{cm}^{-1}$ height) were found. By plotting height-adjusted water use against seedling height, efficient and inefficient water use seedlings could be identified. Inefficient water use seedlings were shorter and had higher water use $\mathrm{cm}^{-1}$ height than efficient water use seedlings. Inefficient water use seedlings were described as having a xeric-water use habit, whereas tall seedlings had a mesic-water use habit. Potentially, height-adjusted water use could be used as a method for selecting individual oak seedlings better adapted to stressful urban planting sites.

Key Words. Dry weight; water use efficiency; xeric- and mesic-site adapted species. Species used in this study. Bur oak (Quercus macrocarpus (Michx.)); pin oak (Q. palustris (Muenchh.)); chestnut oak (Q. prinus (L.)); northern red oak (Q. rubra $(\mathrm{L}))$, (Q. shumardii (Buckl.)), (Q. velutina (Lamb.)).
\end{abstract}

Northern red oak (Quercus rubra L.) is an important and widely distributed tree species in eastern North American forests (Fowells 1975; Harlow et al. 1979). It is considered a keystone species by Spetich et al. (2002) and occurs on a variety of sites and soil types. Optimal development occurs on mesic sites, those sites where soil moisture is least likely to limit to tree growth. In contrast, xeric sites are those characterized soils with limited water availability.

Provenance tests have revealed significant genetic variation for Q. rubra growth rate (Farmer et al. 1981; Schlarbaum and Bagley 1981; Kriebel et al. 1988). Provenance tests are planted with seedlings raised from seeds collected in different parts of a species range. Because the environment at the test site is relatively uniform, differences among individuals are attributed to genetic differences. Under horticultural conditions (container production, transplanting to an agricultural site followed by intensive cultural practices) designed to minimize environmental effects, low age-age correlations for height growth were found (Struve and McKeand, 1993). In the genetic studies, significant within provenance variation was observed (Farmer et al. 1981; Kriebel et al. 1988). It was recommended that further selection efforts should concentrate on phenotypic selection without particular regard to geographic origin (Kriebel et al. 1977). A later study provided the biologic basis for the recommendation; there was weak family clustering within stands (Schwarzmann and Gerhold 1991), although near-neighbors are genetically similar (Sork et al. 1993). That is, trees from different parts of a stand tend not to be closely related, although clusters of trees (nearneighbors) are.

The great phenotypic variability associated with red oak is in part the result of its reproductive biology. It is a wind- 
pollinated outcrossing species with half-sibs likely derived from a large number of pollen parents (Schwarzmann and Gerhold 1991). In the four families studied, there was at least a threefold difference in height growth. Also, within the Quercus subgenera, many hybrids have been described or listed (Palmer 1948; Jensen and Eshbaugh 1976; Jensen et al. 1984; Manos and Fairbrothers, 1987; Tomlinson et al. 2000; Aldrich et al. 2003). Palmer (1948) lists six red oak hybrids (Q. rubra with palustris, ilicifolia, velutina, phellos, shumardii, and imbricaria).

Soil moisture stress and oak water relations have been studied extensively (Abrams 1990), but only two studies describe whole plant water use (Bourdeau 1954; Drunasky and Struve 2005). Under greenhouse conditions, unstressed bur (Quercus macrocarpa) and chestnut oak (Quercus prinus) seedlings used similar amounts of water, although bur oak seedlings were shorter and had less leaf surface area than chestnut oak. Stressed seedlings of both species used less water compared with unstressed seedlings. Quercus macrocarpa seedlings had greater root surface area and root:leaf area ratio than $Q$. prinus seedlings, but root systems of $Q$. prinus seedlings absorbed more water per unit root area per day than $Q$. macrocarpa. Unstressed $Q$. prinus seedlings absorbed 2.2 times more water, whereas stressed seedling absorbed 2.4 times more water than unstressed and stressed $Q$. macrocarpa seedlings. Thus, two drought-resistant species had significantly different growth habits and water use characteristics. Bourdeau (1954) found twofold difference in water use $\mathrm{cm}^{-2}$ leaf surface area among the five oak species studied. Xeric-site adapted species had higher rates of water use relative to mesic species. He also found great variation in water use among individual seedlings within the species studied.

This study describes a series of four experiments conducted to determine the relationship between seedling growth habit and water use characteristics of six oak species. We hypothesize that seedling morphology and water use characters may be used as a screening method to identify drought resistant individuals better able to survive stressful urban planting sites. In the first experiment, Q. shumardii, Q. rubra, and $Q$. velutina, which represent a continuum of wet-mesic to xeric-site adapted species, was studied. In the second experiment, a deep-rooted species ( $Q$. macrocarpa) and two shallow-rooted species $(Q$. palustris and $Q$. prinus) were studied. In the third experiment, two drought-resistant species were studied ( $Q$. macrocarpa and $Q$. prinus). The fourth experiment was conducted to study within family variation in three species: Q. macrocarpa, Q. palustris, and Q. rubra.

\section{MATERIALS AND METHODS}

Four water use experiments were conducted over 10 years under different experimental conditions; however, similar data were collected. The first experiment used acorns col- lected from one red (Quercus rubra) and one black oak $(Q$. velutina) tree and acorns from two Shumard oak ( $Q$. shumardii) trees. The second used bulked acorns from at least three bur $(Q$. macrocarpa), pin ( $Q$. palustris), and chestnut $(Q$. prinus) oaks from each species. The third used acorns collected from one bur and one chestnut oak tree. The fourth used acorns collected from individual bur, pin, and red oak trees and maintained mother tree identity. In the fourth experiment, all acorns were collected from mother trees native to Franklin County, Ohio $\left(40.08^{\circ} \mathrm{N}, 83.07^{\circ} \mathrm{E}\right)$, except for the chestnut oak acorns, which were from trees native to central Indiana (approximately $39.46^{\circ} \mathrm{N}, 86.10^{\circ} \mathrm{E}$ ).

Acorn collection, handling, and germination procedures were similar in all the experiments. Acorns were picked from trees in early to mid- September $\approx 1$ week after the first acorns dropped. Typically, the fallen acorns were heavily infested with weevils; those remaining on the tree were relatively weevil-free. Within $4 \mathrm{hr}$ of collection, the acorns were placed in unsealed plastic bags in a $7^{\circ} \mathrm{C}\left(44.6^{\circ} \mathrm{F}\right)$ refrigerator until sown. In March, acorns were sown in flats (Kandon Corp., Dayton, OH) in Metro Mix 360 (SunGro Horticulture Canada, Ltd., Vancouver, BC) substrate and germinated in a double polycarbonate-glazed greenhouse $\left(25 / 18^{\circ} \mathrm{C}\right.$ [77.0/ $64.4^{\circ} \mathrm{F}$ ], day/night temperature) under natural photoperiods. As soon as shoots emerged, seedlings were removed from the flats, the tap roots pruned to $5 \mathrm{~cm}$ ( 2 in) length, and transplanted to plastic containers using the same substrate. The containers' interior surfaces were coated with Spinout ${ }^{\mathrm{TM}}$ (Griffin Chemical, Co., Valdosta, GA) to encourage root development throughout the growing medium (Arnold and Struve 1993). Seedlings were initially placed container-tocontainer on greenhouse benches and grown under the conditions used for germination. At canopy closure, seedlings were spaced at twice the containers' top dimension where they remained until the experiment was terminated. Seedlings were hand watered as needed to prevent moisture stress. At the beginning of Quercus Morphological Index (QMI) Lag-I (Hanson et al. 1986), the seedlings were fertilized once per week with $100 \mathrm{mg} \mathrm{L}^{-1} \mathrm{~N}$ from a water-soluble fertilizer (20N-8.6P-16.4K, 20 to 20 to 20 Peters; Scotts Miracle Gro, Marysville, OH). An Integrated Pest Management program was used to monitor insect populations, which were controlled with chemical pesticides.

Water use in experiments 2 through 4 was determined by watering seedlings to saturation, allowing the substrate to drain for $1 \mathrm{hr}$ and then weighing the seedlings with an electronic balance (TR-12001; Denver Instrument Company, Denver, CO). Twenty-four (for experiment 2) or 48 (experiments 3 and 4) hr later, the seedlings were reweighed. The difference in weight was divided by the length of the water use period and used as an estimate of daily evapotranspiration referred to as water use for the remainder of the paper. Pre- 
vious water use research (unpublished data) with oak seedlings in covered and uncovered containers under greenhouse conditions showed that evaporation represented approximately $5 \%$ of evapotranspiration. At the end of each water use period, plant height was recorded.

For those studies in which whole plant harvests were done, the following procedures were used. After leaf area was determined with leaf area meter (LiCor Model Li 3,100, Lincoln, NE), roots were washed free of substrate. Root area was determined with a digital image analyzer (Dias II; Decagon Devices, Inc., Pullman, WA, in experiment 1 and with a scanner [Model 5470c scanjet; Hewlett-Packard Co., Boise, ID] and root scanning software [WinRhizo, Version 2002a, Regent Instruments Inc., Canada]) in experiments 2 and 3. Roots from each seedling were separated into two diameter size classes; coarse roots ( $>2 \mathrm{~mm}$ [0.08 in] diameter) and fine roots ( $<2 \mathrm{~mm}$ [0.08 in] diameter). In experiments 2 and 3, a subsample (25\% of the total roots) of the fine roots was scanned, whereas all coarse roots were scanned. During scanning, the roots were floated in water in a clear plastic tray placed on the scanner. After scanning, root samples were placed into individual bags and oven-dried. The remaining fine roots were placed in a third bag and oven-dried. The total fine root area per seedling was estimated by multiplying the ratio of root area to dry weight of the scanned root sample by the total fine root dry weight. After scanning, seedlings were divided into leaf, shoot, and root tissues and oven-dried at $90^{\circ} \mathrm{C}\left(194^{\circ} \mathrm{F}\right)$ for $96 \mathrm{hr}$ before dry weights were recorded. Individual seedling shoot-to-root ratios were calculated by summing an individual's leaf and shoot dry weight and dividing by root dry weight. Specific experimental procedures are listed subsequently.

\section{Experiment 1: Water Use of Quercus rubra, $\mathbf{Q}$. shumardii, and $Q$. velutina Seedlings Under Outdoor Conditions}

Quercus rubra, $Q$. shumardii, and $Q$. velutina seedlings were transplanted to $15 \mathrm{~cm}$ diameter (6 in), $15 \mathrm{~cm}$ (6 in) deep (2.8 L [0.73 gal] No. 1 nursery containers; Nursery Supplies, Fairless Hills, PA) containers and grown under greenhouse conditions described previously until 15 May. They were then moved out doors under $80 \%$ shade cloth for 2 weeks. The seedlings were transplanted to $11.4 \mathrm{~L}$ ([2.96 gal] No. 3 nursery containers, 1200 Classic; Nursery Supplies) using a 3: 0.5:0.5:1 (pine bark:Comtil [composted municipal sewage sludge from the City of Columbus, $\mathrm{OH}$ :peat moss:quartz sand [by vol]) substrate supplemented with $3.6 \mathrm{~kg}(7.92 \mathrm{lb})$ dolomite, $1.2 \mathrm{~kg}(2.64 \mathrm{lb})$ gypsum, and $1.8 \mathrm{~kg}(3.96 \mathrm{lb})$ phosphorus $\mathrm{m}^{-3}$. The seedlings were placed on $45 \mathrm{~cm}$ (18 in) centers in full sun and initially irrigated daily with $1.9 \mathrm{~L}(0.49 \mathrm{gal})$ water and fertilized weekly with $1.9 \mathrm{~L}(0.49 \mathrm{gal})$ of $250 \mathrm{mg}$ $\mathrm{N} \mathrm{L}^{-1}$ water-soluble fertilizer (20 to 20 to 20 Perters fertilizer; Scotts MiracleGro). Irrigation was delivered by $1.9 \mathrm{~L}$ ( 0.49 gal) $\mathrm{hr}^{-1}$ emitters (Netafim ${ }^{\mathrm{TM}}$; Shemin Nurseries, Inc., Addison, IL). The container surfaces were covered with fiber disks to minimize evaporation. In late June, irrigation was controlled by a plant-driven automated irrigation system (Gonzalez and Struve 1992) and the monthly water use calculated as the product of the time the irrigation solenoid was "on" and the trickle irrigation emitter rate. In late August, ten plants per species were harvested. Plant growth, morphology, and irrigation volume data were used to calculate water use seedling $^{-1}, \mathrm{~cm} \mathrm{height}^{-1}, \mathrm{~cm}^{-2}$ leaf area, and $\mathrm{cm}^{-2}$ root surface area. The data were subjected to one-way analysis of variance using a fixed-effects model with ten individual plant replications per species.

\section{Experiment 2: Water Use of $Q$. macrocarpa, $Q$. palustris, and $Q$. prinus Under Greenhouse Conditions}

$Q$. macrocarpa, $Q$. palustris, and $Q$. prinus seedlings were produced under greenhouse conditions as described previously in $12.5 \mathrm{~cm}(5$ in) square $\times 15 \mathrm{~cm}(6$ in) deep containers (250 XL Classic; Nursery Supplies). The seedlings were fertilized weekly with $100 \mathrm{mg} \mathrm{N} \mathrm{L}^{-1}$. The seedlings were grown in a single greenhouse compartment in a completely random design using single plant replications. The numbers of seedlings per species were 107, 253, and 66 for $Q$. macrocarpa, $Q$. palustris, and $Q$. prinus, respectively. When the seedlings reached QMI growth phase, they were watered to saturation, allowed to drain for $1 \mathrm{hr}$, and weighed with an electronic balance (TR-12001; Denver Instrument Co.). The seedlings were reweighed $24 \mathrm{hr}$ later. After the water use trial, 25 seedlings from each species were randomly selected and destructively harvested for dry weight, root and leaf area measurements. Similar water use statistics were calculated like in experiment 1 . Additionally, for the harvested plants, the data were subjected to principal component analysis using 11 variables: height, leaf and root area, shoot, root, total plant and shoot-to-root dry weight, and four measures of water use (water use seedling ${ }^{-1}$, water use $\mathrm{cm}^{-1}$ height, water use $\mathrm{cm}^{-2}$ leaf, and root areas). Data were subjected to analysis of variance using single plant replications a fixed-effects model. Means were separated using Student-Neuman-Kuels test at $P$ $=0.05$ level of significance.

\section{Experiment 3: Water Use of Quercus macrocarpa and $Q$. prinus Under Greenhouse Conditions}

Quercus macrocarpa and $Q$. prinus seedlings were grown in a single greenhouse compartment under conditions described previously. In this study, $2.8 \mathrm{~L}$ (No.1 round nursery containers, $16.5 \mathrm{~cm}$ diameter $\times 17.8 \mathrm{~cm}$ deep [6.6 $\times 7.1 \mathrm{in}]$; Lerio Corp., El Campo, TX) containers filled with Metro Mix 360 substrate were used. Seedlings were hand watered to avoid moisture stress and fertilized weekly after the seedlings 
reached QMI Lag-1 stage with the same fertilizer used in experiment 2 at $100 \mathrm{mg} \mathrm{N} \mathrm{L}^{-1}$. Fertilization was stopped when the water use experiment was begun. For insect control, one $16 \mathrm{~g}(0.56 \mathrm{oz})$ application of imidacloprid (Merit; Bayer Corp., Kansas City, MO) per container was surface applied at QMI Lag-1. Experimental details are described in Drunasky and Struve (2005).

When seedlings from both species reached either Lag-2 or Lag-3 QMI (the second or third flushes), 20 individuals were randomly selected and placed on $45.7 \mathrm{~cm}$ (18.28 in) centers in completely random design. The water use trial was conducted as before, but instead of one $24 \mathrm{hr}$ water use period, two consecutive $48 \mathrm{hr}$ water use periods were used. After the water use trial, seedlings were destructively harvested and height, leaf area, and leaf, root, shoot, plant dry weights, and shoot/root ratios were determined. The same water use statistics, principal component analysis (PCA), and mean separation tests were calculated and analyzed like in experiment 2.

\section{Experiment 4: Water Use of Quercus macrocarpa, $Q$. palustris, and $Q$. rubra Seedlings Under Greenhouse Conditions}

Acorns were collected from two Quercus macrocarpa, three Q. palustris, and $11 Q$. rubra trees in central Ohio. Mother tree identity was maintained throughout the study. Acorns were cold stratified, germinated, transplanted, and grown to QMI Lag-2 or 3 as described in experiment 2. Between 47 and 98 seedlings from each mother tree were raised. Because of the large number of seedlings, three greenhouse compartments (with similar environmental conditions) were used. Two half-sib $Q$. rubra families were common to all three compartments; however, some half-sib $Q$. rubra families were grown in only one compartment. For the common $Q$. rubra families, each compartment was treated as a block with individual seedlings from the half-sib families placed within a compartment in a completely random design. A model A
ET gauge (Ben Meadows Co., Janesville, WI) was placed in each compartment and read at the beginning and end of each water use measurement period. All seedlings within a compartment were weighed on the same day, but seedlings from different compartments were weighed on a staggered schedule. Water use for individual seedlings was standardized by expressing water use statistics as $\mathrm{g}$ water $\operatorname{loss} \mathrm{cm}^{-1} \mathrm{ET}$. Water use was measured over one $48 \mathrm{hr}$ period and average daily water use per seedling calculated. At the end of the water use period, plant height was measured, but no destructive harvests were done because seedlings with apparently efficient and inefficient water use characteristics were used as stock plants in asexual propagation studies. Water use seedling ${ }^{-1}$ and $\mathrm{cm}^{-1}$ height were calculated for all half-sib families. Data were subject to analysis of variance using a fixed-effects model.

\section{RESULTS}

\section{Experiment 1}

Quercus shumardii and Q. rubra seedlings were significantly taller, had greater root length and shoot, root, and total plant dry weights, but lower shoot-to-root ratio than $Q$. velutina seedlings. Additionally, Q. shumardii seedlings had greater leaf and root area than $Q$. velutina seedlings (Table 1). Quercus shumardii seedlings used the most water seedling ${ }^{-1} ; Q$. velutina seedlings used the least (Table 2). However, water use $\mathrm{cm}^{-1}$ of height, water use $\mathrm{cm}^{-2}$ leaf or root surface area was greatest in $Q$. velutina seedling, whereas $Q$. shumardii seedling used the least (Table 2). Growth and water use data were not subjected to PCA as a result of low sample size ( $n=10$ individuals per species).

\section{Experiment 2}

At QMI Lag-2 (the period of time between the second and third growth flushes), $Q$. macrocarpa seedling were taller than $Q$. palustris and $Q$. prinus seedlings (Table 1). Quercus

Table 1. Height, morphology, and dry weights of six oak species in experiments 1, 2, and 3.

\begin{tabular}{|c|c|c|c|c|c|c|c|c|c|c|c|}
\hline \multirow{2}{*}{$\begin{array}{l}\text { Experiment } \\
\text { no. }\end{array}$} & \multirow[b]{2}{*}{ Species } & \multirow[b]{2}{*}{$\mathrm{n}$} & \multirow[b]{2}{*}{$\mathrm{QMI}^{\mathrm{z}}$} & \multirow{2}{*}{$\begin{array}{l}\text { Height } \\
(\mathrm{cm})\end{array}$} & \multicolumn{2}{|c|}{ Surface area $\left(\mathrm{cm}^{2}\right)$} & \multirow{2}{*}{$\begin{array}{c}\text { Root } \\
\text { length }(\mathrm{cm})\end{array}$} & \multicolumn{3}{|c|}{ Dry weight (g) } & \multirow{2}{*}{$\begin{array}{l}\text { Shoot to } \\
\text { root ratio }\end{array}$} \\
\hline & & & & & Leaf & Root & & Shoot & Root & Total & \\
\hline \multirow[t]{3}{*}{1} & Q. rubra & 10 & 3 to 4 & $50.6 \mathrm{~b}^{\mathrm{y}}$ & $1190.7 \mathrm{ab}$ & $457.1 \mathrm{ab}$ & $5001.3 \mathrm{~b}$ & $24.9 \mathrm{~b}$ & $25.0 \mathrm{~b}$ & $49.0 \mathrm{~b}$ & $1.0 \mathrm{a}$ \\
\hline & Q. shumardii & 10 & 3 to 4 & $63.1 \mathrm{~b}$ & $1596.8 \mathrm{~b}$ & $648.0 \mathrm{~b}$ & $5436.2 \mathrm{~b}$ & $22.4 \mathrm{~b}$ & $17.6 \mathrm{~b}$ & $40.0 \mathrm{~b}$ & $1.3 \mathrm{a}$ \\
\hline & Q. velutina & 10 & 2 to 3 & $29.6 \mathrm{a}$ & $737.8 \mathrm{a}$ & $328.6 \mathrm{a}$ & $3014.3 \mathrm{a}$ & $8.2 \mathrm{a}$ & $4.8 \mathrm{a}$ & $13.0 \mathrm{a}$ & $1.7 \mathrm{~b}$ \\
\hline \multirow[t]{3}{*}{2} & Q. macrocarpa & 25 & 2 & $31.0 \mathrm{~b}$ & $634.9 \mathrm{c}$ & $168.2 \mathrm{c}$ & $1265.2 \mathrm{~b}$ & $7.3 \mathrm{~b}$ & $7.7 \mathrm{~b}$ & $15.0 \mathrm{c}$ & $1.1 \mathrm{a}$ \\
\hline & Q. palustris & 25 & 2 & $21.1 \mathrm{a}$ & $203.2 \mathrm{a}$ & $83.2 \mathrm{a}$ & $661.4 \mathrm{a}$ & $2.4 \mathrm{a}$ & $2.2 \mathrm{a}$ & $4.6 \mathrm{a}$ & $1.1 \mathrm{a}$ \\
\hline & $Q$. prinus & 25 & 2 & $19.3 \mathrm{a}$ & $463.1 \mathrm{~b}$ & $102.7 \mathrm{~b}$ & $692.4 \mathrm{a}$ & $3.8 \mathrm{a}$ & $2.7 \mathrm{a}$ & $6.5 \mathrm{~b}$ & $1.4 \mathrm{~b}$ \\
\hline \multirow[t]{2}{*}{3} & Q. macrocarpa & 20 & 3 to 4 & $43.9 \mathrm{a}$ & $1414.4 \mathrm{a}$ & $138.0 \mathrm{~b}$ & $1271.7 \mathrm{~b}$ & $16.5 \mathrm{a}$ & $31.0 \mathrm{~b}$ & $47.5 \mathrm{~b}$ & $0.5 \mathrm{a}$ \\
\hline & Q. prinus & 20 & 3 to 4 & $81.9 \mathrm{~b}$ & $1882.5 \mathrm{~b}$ & $71.2 \mathrm{a}$ & $169.4 \mathrm{a}$ & $21.5 \mathrm{~b}$ & $9.5 \mathrm{a}$ & $31.0 \mathrm{a}$ & $2.3 \mathrm{~b}$ \\
\hline
\end{tabular}

${ }^{\mathrm{z}}$ Quercus morphologic index are for the lag-phase (Hanson et al. 1986).

${ }^{\mathrm{y}}$ Means within an experiment and column followed by different letters are significantly different from each other using the Student-Neuman-Kels test at the $\propto=0.05$ level of significance. 
Table 2. Water use of six oak species in experiments 1, 2, and 3.

\begin{tabular}{lllclc}
\hline & & \multicolumn{3}{c}{ Water use $\left(\mathrm{g}\right.$ water per day $\left.{ }^{-1}\right)$} \\
\cline { 3 - 5 } Experiment no. & & & $\mathrm{cm}^{-2}$ area \\
\cline { 3 - 6 } 1 & Species & Seedling $^{-1}$ & $\mathrm{~cm}^{-1}$ height & Leaf & Root \\
\hline & Q. rubra & $463.2 \mathrm{~b}^{\mathrm{z}}$ & $9.2 \mathrm{a}$ & $0.39 \mathrm{a}$ & $1.0 \mathrm{ab}$ \\
& Q. shumardii & $510.6 \mathrm{c}$ & $8.1 \mathrm{a}$ & $0.32 \mathrm{a}$ & $0.8 \mathrm{a}$ \\
& Q. velutina & $353.4 \mathrm{a}$ & $11.9 \mathrm{~b}$ & $0.48 \mathrm{~b}$ & $1.1 \mathrm{~b}$ \\
& Q. macrocarpa & $131.7 \mathrm{~b}$ & $4.5 \mathrm{a}$ & $0.55 \mathrm{a}$ & $0.9 \mathrm{a}$ \\
& Q. palustris & $102.3 \mathrm{a}$ & $5.1 \mathrm{a}$ & $0.60 \mathrm{a}$ & $1.5 \mathrm{~b}$ \\
& Q. prinus & $103.9 \mathrm{a}$ & $5.9 \mathrm{~b}$ & $0.33 \mathrm{a}$ & $0.3 \mathrm{ab}$ \\
& Q. macrocarpa & $156.2 \mathrm{a}$ & $4.3 \mathrm{~b}$ & $0.12 \mathrm{~b}$ & $1.3 \mathrm{a}$ \\
& Q. prinus & $163.0 \mathrm{a}$ & $2.1 \mathrm{a}$ & $0.09 \mathrm{a}$ & $2.8 \mathrm{~b}$ \\
\hline
\end{tabular}

${ }^{\mathrm{z}}$ Means within an experiment and column followed by different letters are significantly different from each other using the Waller-Duncan test at the $\propto=0.05$ level of significance.

macrocarpa seedlings also had greatest leaf and root surface area and $Q$. palustris seedlings the least. Quercus macrocarpa seedlings had greater root length and shoot and root dry weights than $Q$. palustris and $Q$. prinus seedlings. Quercus macrocarpa seedlings had the greatest total plant dry weight and $Q$. palustris seedlings the least. $Q$. prinus seedlings had a greater shoot-to-root dry weight ratio than $Q$. macrocarpa and $Q$. palustris seedlings.

Quercus macrocarpa seedling had higher water use seedling $^{-1}$ than $Q$. palustris and $Q$. prinus seedlings, but $Q$. prinus seedlings had the greatest water use $\mathrm{cm}^{-1}$ height (Table 2). There was no difference in water use $\mathrm{cm}^{-2}$ leaf surface area among seedlings of the three species (Table 2). Quercus macrocarpa seedlings used the least amount of water $\mathrm{cm}^{-2}$ root surface area; Q. palustris seedling used the greatest (Table 2).

Principal component analysis revealed that $86 \%$ and $88 \%$ of the total variation could be explained by the first three components for $Q$. macrocarpa and $Q$. prinus, respectively, whereas $86 \%$ of the total variation for $Q$. palustris could be explained by the first two components (Table 3). For all species, growth factors (height, leaf area, and shoot, root, and total plant dry weight and water use seedling ${ }^{-1}$ ) loaded positively on the first component; the other water use factors loaded negatively. The water use factors loaded differently on the second and third principal components.

\section{Experiment 3}

Quercus macrocarpa seedling were shorter, had less leaf area, lower shoot dry weight and shoot to root ratio, but greater root surface area, root length, root and total plant dry weight than $Q$. prinus seedlings (Table 1 ). There was no difference in water use seedling ${ }^{-1}$ between the species, but $Q$. macrocarpa seedlings had greater water use $\mathrm{cm}^{-1}$ height and water use $\mathrm{cm}^{-2}$ leaf area but lower water use $\mathrm{cm}^{-2}$ root sur-

Table 3. Principal component correlation matrixes for Quercus macrocarpa, Q. palustris, and Q. prinus seedlings in experiment 2.

\begin{tabular}{|c|c|c|c|c|c|c|c|c|}
\hline \multirow[b]{3}{*}{ Variable } & \multicolumn{8}{|c|}{ Component } \\
\hline & \multicolumn{3}{|c|}{ Q. macrocarpa } & \multicolumn{2}{|c|}{ Q. palustris } & \multicolumn{3}{|c|}{ Q.prinus } \\
\hline & 1 & 2 & 3 & 1 & 2 & 1 & 2 & 3 \\
\hline Height & 0.74 & -0.34 & -0.38 & 0.83 & -0.43 & 0.82 & -0.02 & 0.03 \\
\hline Leaf area & 0.85 & -0.11 & 0.32 & 0.93 & -0.19 & 0.85 & 0.47 & 0.08 \\
\hline Root area & 0.83 & 0.36 & -0.3 & 0.92 & 0.34 & 0.89 & -0.32 & 0.16 \\
\hline Dry weight shoot & 0.95 & -0.07 & 0.04 & 0.97 & -0.08 & 0.94 & 0.27 & 0.15 \\
\hline Root & 0.88 & 0.31 & -0.07 & 0.92 & 0.32 & 0.88 & -0.23 & 0.33 \\
\hline Total plant & 0.95 & 0.15 & -0.02 & 0.97 & 0.14 & 0.96 & 0.08 & 0.23 \\
\hline Water use seedling ${ }^{-1}$ & 0.84 & 0.13 & 0.32 & 0.86 & -0.09 & 0.74 & 0.56 & 0.20 \\
\hline $\mathrm{cm}^{-1}$ height & -0.37 & 0.66 & 0.65 & -0.67 & 0.49 & -0.66 & 0.35 & 0.27 \\
\hline $\mathrm{cm}^{-2}$ leaf area & -0.62 & 0.53 & -0.28 & -0.83 & 0.39 & -0.66 & 0.09 & 0.67 \\
\hline $\mathrm{cm}^{-2}$ root area & -0.80 & -0.24 & 0.05 & -0.86 & -0.10 & -0.67 & 0.41 & 0.55 \\
\hline Shoot-to-root ratio & 0.41 & 0.82 & -0.34 & 0.23 & 0.88 & -0.36 & -0.70 & 0.55 \\
\hline Cumulative percent of total variation explained & 62.0 & 78.3 & 86.8 & 71.5 & 86.2 & 62.7 & 76.8 & 88.5 \\
\hline
\end{tabular}


face area (Table 2). Four components explained $88 \%$ of the total variation for $Q$. macrocarpa, whereas three components explained $86 \%$ of the variation for $Q$. prinus (Table 4). In both species, the growth factors and water use seedling ${ }^{-1}$ loaded positively on the first component, whereas the other water use factors loaded negatively except in $Q$. prinus in which water use seedling ${ }^{-1}$ loaded negatively on the first principal component. Like in experiment 2, there was little consistency between the two species in which factors loaded positively and negatively on the other principal components.

\section{Experiment 4}

Evapotranspiration during the three $48 \mathrm{hr}$ water use periods was 3,9 , and $5 \mathrm{~mm}(0.12,0.36,0.20$ in) for the periods of 19 to 21,21 to 23 , and 20 to 22 July, respectively. Therefore, water use was standardized by dividing the water use statistics by the corresponding ET values, which generated the following water use statistics: $\mathrm{g}$ water use seedling $\mathrm{g}^{-1} \mathrm{~cm}^{-1} \mathrm{ET}$ day $^{-1}$ and $\mathrm{g}$ water use $\mathrm{cm}^{-1}$ height $\mathrm{cm}^{-1}$ ET day ${ }^{-1}$. To simplify the presentation of water use data, the $\mathrm{cm}^{-1}$ ET day ${ }^{-1}$ term will be dropped. The resulting water use statistics were subjected to analysis of variance using a fixed-effects model. The authors note that although greenhouse compartments were kept as similar as possible, microclimate differences among the greenhouse compartments and differences in environmental conditions among the three water use study periods are confounded. We refer to a "greenhouse compartment effect" for convenience, recognizing that statistical differences may be the result of differences in the adjacent compartments and/or differences in environmental conditions affecting ET. For the two Q. rubra families common to all three greenhouse compartments, there were no significant family by greenhouse compartment effects for water use $\mathrm{cm}^{-1}$ height $(P=0.81)$ or water use seedling ${ }^{-1}(P=0.06)$.
There were two additional families (one $Q$. rubra and one $Q$. palustris) that were grown in two greenhouse compartments. For those seedlings, there were no significant greenhouse compartment effects for water use (either water use seedling ${ }^{-1}$ or $\mathrm{cm}^{-1}$ height, data not presented). Thus, adjusting daily water use by ET and time was an effective method of standardizing water use. For the two families common to all greenhouse compartments, there was a significant family by greenhouse compartment effect for seedling height $(P=$ 0.001 ); seedlings of the $Q$. rubra family 27 were shorter in one greenhouse compartment than in the other two (30.5 versus 51.7 and $49.8 \mathrm{~cm}$ [12.2 versus 20.7 and 19.9 in]). For seedlings of the other $Q$. rubra family (family 35), average height among the compartments was similar: 52.1, 59.1, and $49.2 \mathrm{~cm}(20.8,23.6$, and $19.7 \mathrm{in}, \mathrm{SE} \AA 4.6 \mathrm{~cm}$ [1.8 in]). Thus, height and ET-adjusted water use data from all the half-sib families were combined over greenhouse compartments and analyzed by species using the one-way analysis of variance (ANOVA) procedure within SPSS using a completely random design with single plant replications in a fixed-effects model. A two-way ANOVA (species by family) was not possible because of the low number of $Q$. macrocarpa and $Q$. palustris families.

There were no significant differences between species in seedling height. Average seedling height for Q. macrocarpa, $Q$. palustris, and $Q$. rubra were $36.5,49.9$, and $46.9 \mathrm{~cm}$ (14.6, $20,18.8$ in Table 5). There were significant differences in the water use characteristics ( $\mathrm{g}$ water seedling ${ }^{-1}$ and $\mathrm{cm} \mathrm{height}^{-1}$ ) among the species $(P=0.001$, and 0.001 , respectively $)$. Water use seedling ${ }^{-1}$ for $Q$. macrocarpa, $Q$. palustris, and $Q$. rubra was 391.3, 562.6, and $466.4 \mathrm{~g}(13.7,19.7,16.3 \mathrm{oz})$, respectively (Table 5) and water use $\mathrm{cm}^{-1}$ height was 12.7 , 12.6 , and $12.2 \mathrm{~g}\left(0.445,0.441,0.427 \mathrm{oz} \mathrm{in}^{-1}\right.$ height $)$, respectively (Table 5). Within all three species, there were signifi-

Table 4. Principal component matrixes for Quercus macrocarpa and Q. prinus seedlings in experiment 3.

\begin{tabular}{|c|c|c|c|c|c|c|c|}
\hline \multirow[b]{2}{*}{ Variable } & \multicolumn{7}{|c|}{ Component } \\
\hline & 1 & 2 & 3 & 4 & 1 & 2 & 3 \\
\hline Height & 0.90 & 0.13 & -0.26 & -0.13 & 0.14 & 0.91 & -0.26 \\
\hline Leaf area & 0.87 & 0.30 & -0.17 & -0.17 & 0.26 & 0.83 & -0.31 \\
\hline Root area & 0.40 & -0.20 & -0.71 & 0.46 & 0.80 & -0.07 & -0.26 \\
\hline Total plant & 0.46 & -0.75 & -0.42 & 0.12 & 0.79 & 0.06 & 0.60 \\
\hline Water use seedling ${ }^{-1}$ & 0.54 & 0.64 & -0.09 & -0.01 & -0.37 & 0.88 & 0.13 \\
\hline $\mathrm{cm}^{-1}$ height & -0.84 & 0.26 & 0.03 & 0.17 & -0.65 & -0.08 & 0.55 \\
\hline $\mathrm{cm}^{-2}$ leaf area & -0.82 & 0.08 & 0.09 & 0.21 & -0.78 & 0.01 & 0.55 \\
\hline $\mathrm{cm}^{-2}$ root area & -0.19 & 0.54 & 0.65 & -0.40 & -0.69 & 0.64 & 0.23 \\
\hline
\end{tabular}


Table 5. Water use of three Quercus species in experiment 4.

\begin{tabular}{|c|c|c|c|c|c|}
\hline \multirow[b]{2}{*}{ Species } & \multirow[b]{2}{*}{ Family } & \multirow[b]{2}{*}{$\mathrm{n}$} & \multirow[b]{2}{*}{ Height (cm) } & \multicolumn{2}{|c|}{ Water use (g water day ${ }^{-1} \mathrm{~cm} \mathrm{ET}^{-1}$ ) } \\
\hline & & & & Seedling & $\mathrm{cm}$ height \\
\hline \multirow[t]{3}{*}{ Q. macrocarpa } & 25 & 84 & $32.4(15.3)^{\mathrm{z}}$ & $447.1(174.9)$ & $16.3(8.4)$ \\
\hline & 34 & 93 & $40.2(14.2)$ & $388.0(83.1)$ & $10.7(3.2)$ \\
\hline & species avg. & & $36.5(15.1)$ & $391.3(144.4)$ & $12.7(7.1)$ \\
\hline \multirow[t]{4}{*}{ Q. palustris } & 20 & 98 & $41.7(25.8)$ & 360.9 (81.9) & $10.6(3.6)$ \\
\hline & 28 & 96 & $64.7(20.0)$ & 771.7 (223.9) & $12.7(4.0)$ \\
\hline & 30 & 76 & $44.5(15.8)$ & $597.8(166.5)$ & $14.8(6.1)$ \\
\hline & species avg. & & 49.9 (23.9) & $552.6(227.6)$ & $12.6(5.0)$ \\
\hline \multirow[t]{12}{*}{ Q. rubra } & 21 & 86 & $63.9(31.1)$ & $476.9(134.6)$ & $9.1(4.2)$ \\
\hline & 22 & 70 & $26.4(16.5)$ & $313.6(90.4)$ & $14.2(4.6)$ \\
\hline & 23 & 94 & $58.8(27.5)$ & $483.6(114.5)$ & $9.8(4.2)$ \\
\hline & 24 & 47 & $39.6(17.4)$ & $333.4(103.5)$ & $9.1(2.3)$ \\
\hline & 26 & 63 & $38.4(20.8)$ & $469.5(146.5)$ & $14.5(6.0)$ \\
\hline & 27 & 98 & $46.2(23.0)$ & $475.9(138.3)$ & $12.7(6.4)$ \\
\hline & 29 & 81 & $55.2(23.3)$ & $394.4(111.8)$ & $7.8(2.5)$ \\
\hline & 31 & 75 & $40.3(17.4)$ & 353.7 (99.4) & $9.8(3.3)$ \\
\hline & 32 & 89 & $46.6(81.6)$ & $412.1(14.1)$ & $9.8(3.9)$ \\
\hline & 33 & 92 & 37.0 (21.9) & $683.5(183.4)$ & $24.4(12.0)$ \\
\hline & 35 & 80 & $54.9(18.8)$ & $636.8(234.5)$ & $12.5(5.0)$ \\
\hline & species avg. & & $46.9(24.3)$ & $466.4(176.0)$ & $12.2(7.4)$ \\
\hline
\end{tabular}

${ }^{\mathrm{z}}$ Values within parentheses are the standard deviation of the mean.

cant $(P=0.001)$ level within family differences in seedling height and both water use measures.

Correlations (conducted by species after combining over all half-sib families within a species) between plant height and water use characteristics revealed that seedling height was positively correlated with $\mathrm{g}$ water use seedling ${ }^{-1}$ but negatively correlated with water use $\mathrm{cm}^{-1}$ seedling height. Water use seedling ${ }^{-1}$ was not significantly correlated with water use $\mathrm{cm}^{-1}$ height (Table 6). Correlations for individuals within half-sib families for each species revealed similar correlations; height was positively and significantly correlated with water use seedling ${ }^{-1}$ but weakly negatively correlated with water use $\mathrm{cm}^{-1}$ seedling height (Figures $1 \mathrm{~A}$ and B show these relationships for $Q$. rubra family 23). The correlations between water use seedling ${ }^{-1}$ and water use adjusted for $\mathrm{cm}^{-1}$ seedling height were not significant with the following exceptions: Q. palustris family 20 and $Q$. rubra families 22,23 , 32,33 , and 35 were significant (Table 6). Plotting heightadjusted water use $\left(\mathrm{cm}^{-1}\right.$ seedling height) against seedling height generated reciprocal curves (Figure 2). This was used as a means of discriminating between tall seedlings with efficient water use and short seedlings with inefficient water use.

\section{DISCUSSION}

The Quercus species used in this study have been classified according to their relative drought tolerance. Quercus velutina and $Q$. prinus have been classified as the most drought-
Table 6. Correlation between height and various water use characteristics for Quercus macrocarpa, $Q$. palustris, and $Q$. rubra seedlings in QMI Lag-3 to 4 growth stage (experiment 4).

\begin{tabular}{|c|c|c|c|c|c|}
\hline \multirow[b]{2}{*}{ Species } & \multirow[b]{2}{*}{ Family } & \multirow[b]{2}{*}{$\mathrm{n}$} & \multicolumn{3}{|c|}{ Correlation $^{\mathrm{z}}$} \\
\hline & & & 1 & 2 & 3 \\
\hline \multirow{2}{*}{ Q. macrocarpa } & 25 & 84 & $0.63^{y}$ & -0.02 & -0.63 \\
\hline & 34 & 93 & 0.59 & -0.13 & -0.81 \\
\hline All families & & 177 & 0.44 & 0.05 & -0.66 \\
\hline \multirow[t]{3}{*}{$Q$. palustris } & 20 & 98 & 0.72 & -0.53 & -0.89 \\
\hline & 28 & 96 & 0.56 & 0.18 & -0.65 \\
\hline & 30 & 76 & 0.52 & 0.18 & -0.66 \\
\hline All families & & 250 & 0.59 & 0.20 & -0.55 \\
\hline \multirow[t]{11}{*}{ Q. rubra } & 21 & 86 & 0.59 & -0.16 & -0.82 \\
\hline & 22 & 70 & 0.77 & -0.37 & -0.80 \\
\hline & 23 & 93 & 0.68 & -0.20 & -0.79 \\
\hline & 24 & 47 & 0.82 & -0.18 & -0.68 \\
\hline & 26 & 63 & 0.65 & -0.06 & -0.71 \\
\hline & 27 & 98 & 0.38 & 0.12 & -0.78 \\
\hline & 29 & 81 & 0.71 & -0.07 & -0.70 \\
\hline & 31 & 75 & 0.76 & -0.21 & -0.74 \\
\hline & 32 & 89 & 0.17 & -0.26 & -0.81 \\
\hline & 33 & 92 & 0.72 & -0.42 & -0.84 \\
\hline & 35 & 80 & 0.62 & -0.26 & -0.50 \\
\hline All families & & 895 & 0.47 & -0.19 & -0.62 \\
\hline
\end{tabular}




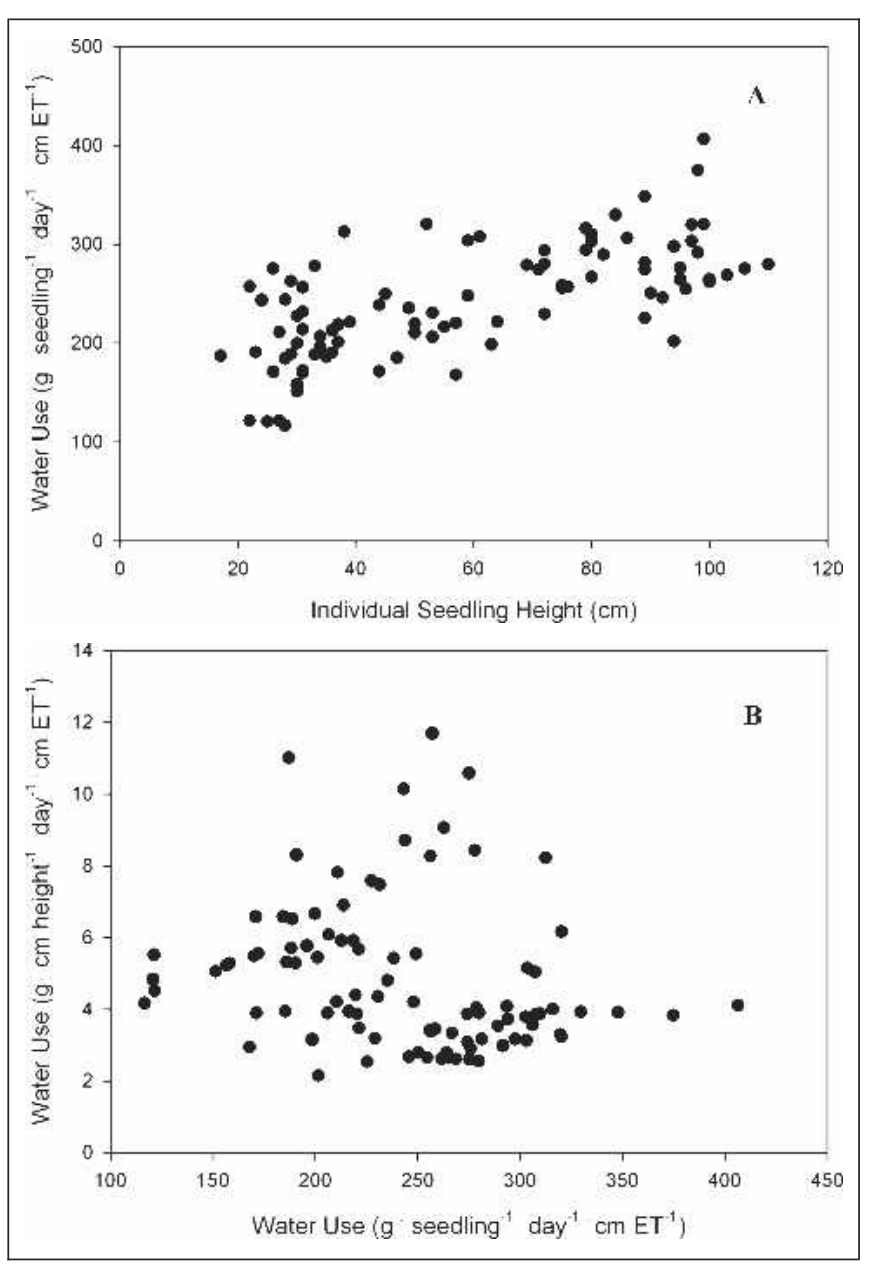

Figure 1. (A and B) Seedling water use expressed relative to seedling height: as $\mathrm{g}$ water use seedling ${ }^{-1} \mathrm{~cm} \mathrm{ET}^{-1}$ $\mathrm{day}^{-1}(\mathrm{~A})$ or as height-adjusted water use: $\mathrm{g}$ water use seedling ${ }^{-1} \mathrm{~cm} \mathrm{ET}^{-1}$ day $^{-1}$ versus $\mathrm{g}$ water use $\mathrm{cm}^{-1}$ height $\mathrm{cm} \mathrm{ET}^{-1}$ day $^{-1}$ in Quercus rubra family 23.

tolerant, $Q$. rubra and $Q$. macrocarpa as intermediate drought-tolerant, and $Q$. palustris and $Q$. shumardii as the least (Dickson and Tomlinson 1996). A similar order of drought tolerance was recognized by Abrams (1990); although he classified $Q$. shumardii as a xeric species in the central plains. We considered the $Q$. shumardii mother tree used in our study as a mesic site-adapted individual. It was located in central Ohio on a site with a deep clay-loam soil.

Seeds were collected from trees in central Ohio without regard to ecologic niche; thus, the results are specific to these mother trees. Although the four water use experiments were conducted under different environmental conditions and with different aged seedlings, there was a pattern between seedling morphology and water use. The xeric site-adapted species had lower dry weights, smaller heights, and lower shoot/root ratios than the mesic site-adapted species. Similar relation-

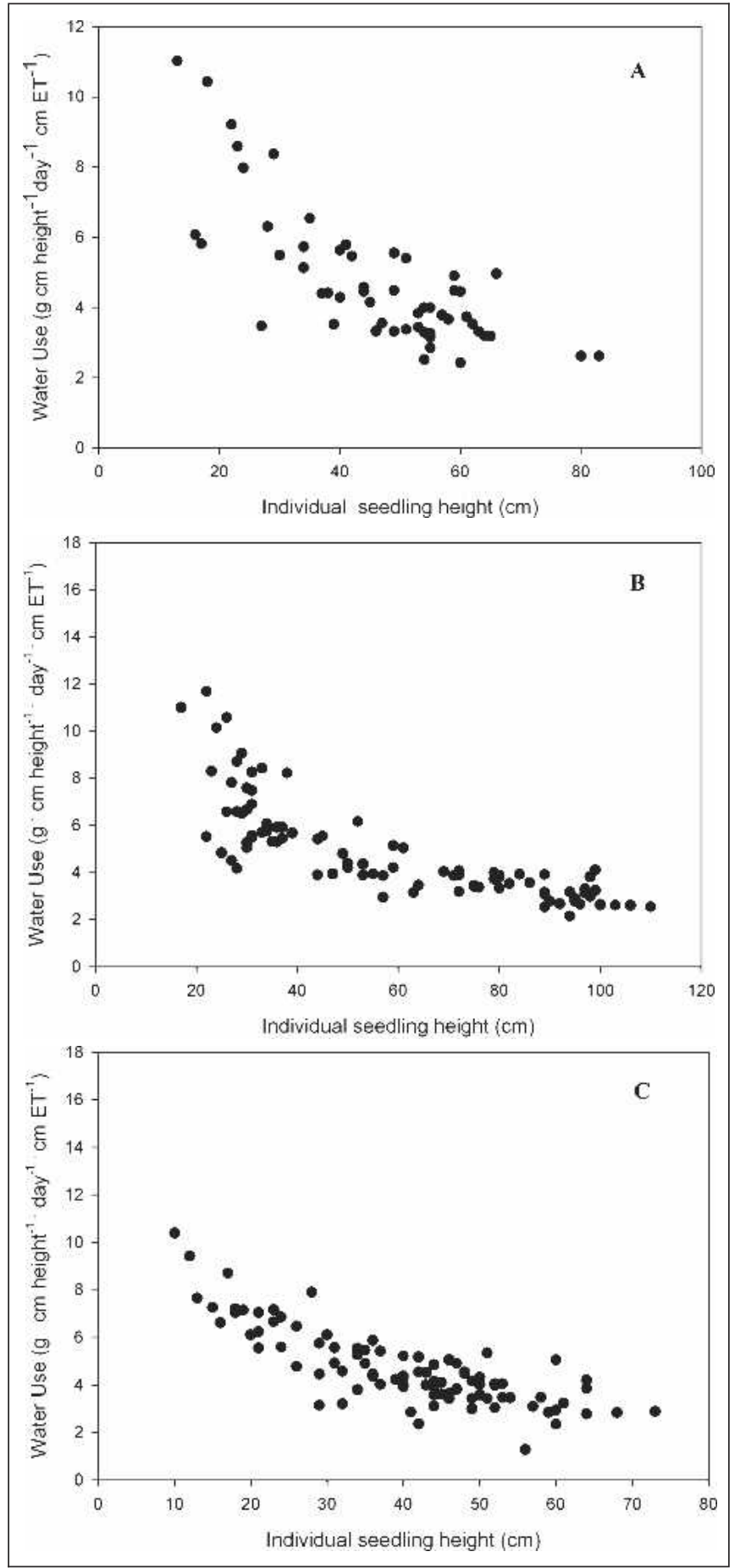

Figure 2. Height-adjusted water use expressed relative to individual seedling height in Quercus rubra family 23 (A) Q. macrocarpa family 35 (B) in Quercus palustris family 30 (C).

ships were found between xeric and mesic site-adapted species studied by Bourdeau (1954), Farmer (1979), and Long and Jones (1996). Within experiments, xeric species had greater root area than mesic species. There was one excep- 
tion: $Q$. velutina seedlings in experiment 1 had the lowest root area and highest shoot/root ratio.

There was no consistent pattern between water use seed$\operatorname{ling}^{-1}$ and relative drought resistance. For all species in experiments 2,3 , and 4 , water use seedling ${ }^{-1}$ loaded positively on principal component 1 , as did seedling height, leaf area, root area and shot, root and total plant dry weight (factors that describe seedling size). Thus, not unexpectedly, larger seedlings tended to used more water than shorter seedlings. The one exception was $Q$. prinus seedlings, in which water use seedling ${ }^{-1}$ loaded negatively on principal component 1 . However, the other measures of water use:water use $\mathrm{cm}^{-1}$ height, $\mathrm{cm}^{-2}$ leaf or $\mathrm{cm}^{-2}$ root surface area, loaded negatively on principal component 1 , indicating that smaller seedlings with less leaf area, root area, and total dry weight had higher water use $\mathrm{cm}^{-1}$ height, $\mathrm{cm}^{-2}$ leaf area, and $\mathrm{cm}^{-2}$ root surface area than larger seedlings.

In general, the most drought-resistant species had the highest water use $\mathrm{cm}^{-1}$ height and $\mathrm{cm}^{-2}$ leaf surface area. Water use $\mathrm{cm}^{-2}$ root surface area (a measure of water absorbing efficiency) was not related to relative drought resistance. For instance, the most drought-resistant species in experiment 1, $Q$. velutina, and the most drought-resistant species in experiment 3, $Q$. prinus, had the highest water use $\mathrm{cm}^{-2}$ root surface area. In contrast, the least drought-resistant species in experiment 2, $Q$. palustris, had a more efficient water-absorbing root system than the most drought-resistant species, $Q$. macrocarpa. Our expectation was that xeric site-adapted species would have both high water use $\mathrm{cm}^{-1}$ height and $\mathrm{cm}^{-2}$ leaf surface area and an efficient water-absorbing root system. However, there was not a consistent relationship among these factors. They loaded differently for each species on the principal components (Tables 4 and 5). It is logical that sympatric species (species that inhabit a common area) would have evolved different responses to water stress. Dickson and Tomlinson (1996) argue that because of the wide range of sites occupied by oaks, there would not be a common response to water stress.

In experiment 4 , there were sufficient numbers of seedlings per family to develop correlations between seedling height and water use. Three correlations were developed: seedling height versus seedling water use, seedling water use versus height-adjusted water use, and seedling height versus heightadjusted water use. For all species in experiment 4, the correlations between seedling water use and height-adjusted water use were not significant (water use seedling ${ }^{-1}$ and water use $\mathrm{cm}^{-1}$ height). The correlations between seedling height and water use seedling ${ }^{-1}$ were positively and significantly correlated. Not surprisingly, taller seedlings used more water day $^{-1}$ than short seedlings. In contrast, the correlations between seedling height and water use $\mathrm{cm}^{-1}$ height were negatively and significantly correlated. These correlations are graphed for Quercus rubra family 23 (Figures 1A and B and
2A). We plotted height-adjusted water use $\left(\mathrm{g}\right.$ water $\mathrm{cm}^{-1}$ height) against seedling height as a way of identifying apparently efficient and inefficient water use seedlings. Efficient water use seedlings were those with low height-adjusted water use: tall seedlings with low water use $\mathrm{cm}^{-1}$ height. We felt that seedlings with low height-adjusted water use were not experimental artifacts. Efficient water use seedlings could have been falsely identified because they transpired so much substrate moisture that substrate moisture limited transpiration before the $48 \mathrm{hr}$ water use period ended. However, at the end of the $48 \mathrm{hr}$ water use period, the substrate in containers with large seedlings was still moist to the touch. Furthermore, we estimated that half the plant available water had been transpired by the end of the $48 \mathrm{hr}$ water use period (see Drunasky and Struve 2005). Experiment 4 also showed similar relationships between seedling height and height-adjusted water use for both Quercus macrocapra families and in two of three $Q$. palustris families. The one exception was for $Q$. palustris family 20 in which the correlation between seedling height and height-adjusted water use was negative (Table 6). More $Q$. palustris families need to be tested to determine the nature of the relationship between seedling height and heightadjusted water use for $Q$. palustris.

We considered short seedlings with relatively high heightadjusted water use to have a xeric water use pattern. Bunce et al. (1977) suggested that "inefficient" water use characteristic of slower growing, shade-intolerant early successional seedlings adapted to xeric sites may be a mechanism to increase its competitive ability. Xeric site-adapted species have a conservative growth habit; they invest proportionally more in root growth than shoot growth, thereby increasing their drought resistance. Also, xeric site-adapted species tend to have superior drought tolerance (Abrams 1990). The benefit of preferential investment in root mass is the ability to maintain net photosynthesis at lower soil moisture potentials than species adapted to mesic sites. Thus, on xeric sites, seedlings with a xeric growth habit survive in stressful environments, whereas mesic species die or suffer reduced grow rates; low soil moisture potential reduces leaf growth of mesic siteadapted species such as Q. rubra (Dickson and Tomlinson 1996). By actively lowering soil moisture, xeric-adapted species alter the soil environment to their competitive advantage. This phenomena has been termed competitive exploitation of soil moisture (Bunce et al. 1977).

We found that within the half-sib families studied, there was a range of mesic to xeric site-adapted seedlings. We propose that those $Q$. rubra seedlings with a xeric morphology and water use pattern represents introgression of drought resistance genes from more a drought-resistant species such as Q. veltuina. Quercus rubra is genetically diverse (Burger 1975; Jensen and Eshbaugh 1976; Jensen 1977; Houston 1983; Manos and Fairbrothers 1987; Guttman and Weig 1988; Kriebel et al. 1988; Schwarzmann and Gerhold 1991; 
Aldrich et al. 2003) and known to hybridize with at least seven other oak species (ilicifoia, imbricaria, palustris, phellos, shumardii, velutina, [Palmer 1948], Q ellipsoidalis [Hokanson et al. 1993]). In the Hokanson et al. (1993) study, $Q$. rubra and the Q. rubra $\times$ Q. ellipsoidalis hybrids could not be distinguished by morphologic traits, but morphologic traits could be used to identity $Q$. rubra and $Q$. ellipsoidalis (Tomlinson et al. 2000). In our study, although the $Q$ rubra mother trees and their progeny appeared morphologically true to type, it is likely that hybrids would have been undetected. Similarly, hybrids or gene flow could be contributing to the within-family variation in morphology and water use of $Q$. palustris and Q. macrocarpa seedlings.

We suggest that $Q$, macrocarpa, $Q$. palustris, $Q$. prinus, $Q$. rubra, $Q$. shumardii, and $Q$. velutina seedlings with high height-adjusted water use are better adapted to drier sites than are those seedlings with low height-adjusted water. Untested is the assumption is that those seedlings with xeric morphology and high height-adjusted water use also have greater drought tolerance. Clonal material is needed to confirm the genetic basis of the differing within species water use characteristics and the relationship among seedling morphology, water use characteristics, and drought tolerance. Clonal propagation of seedlings with xeric and mesic water use characteristics and morphologies identified in experiment 4 is being done at The Ohio State University.

In conclusion, xeric and mesic seedling morphology and water use characteristics were described for six oak species. Xeric morphology was evidenced by relatively slower height growth and lower shoot:root ratios than seedlings with mesic morphology. A xeric water use pattern was characterized by relatively high height-adjusted water use $\left(\mathrm{g}\right.$ water used $\mathrm{cm}^{-1}$ height day $^{-1}$ ). Mesic water use seedlings were characterized by low height-adjusted water use and more rapid height growth. It may be possible to use seedling morphology and water use characteristics to increase "dominance probability" by better matching planting stock with planting sites by acknowledging within-species differences in growth and water use characteristics. If xeric water use pattern, morphology, and greater drought tolerance are linked, then nursery stock most suited to stressful urban forestry use will take longer to produce and use more water during production than seedlings with mesic characteristics. Consumers who specify planting stock with the xeric growth and water use characteristics should be willing to compensate nursery producers for their higher production costs and longer rotation times, because they will receive nursery stock with better "fitness to purpose."

\section{LITERATURE CITED}

Abrams, M.D. 1990. Adaptions and responses to drought in Quercus species of North America. Tree Physiology 7: 227-238.
Aldrich, P.R., B.R. Parker, C.H. Michler, and J. FomeroSeverson. 2003. Whole-tree silvic identification and the microsatellite genetic structure of a red oak species complex in an Indiana old-growth forest. Canadian Journal of Forest Research 33:2228-2237.

Arnold, M.A., and D.K. Struve. 1993. Root distribution and mineral uptake of coarse-rooted trees grown in cupric hydroxide-treated containers. HortScience 28:988-992.

Bourdeau, P. 1954. Oak seedling ecology determining segregation of species. Ecological Monographs 24:297-320.

Bunce, J.A., L.N. Miller, and B.F. Chabot. 1977. Competitive exploitation of soil water by five eastern North American tree species. Botanical Gazette 138:168-173.

Burger, W.C. 1975. The species concept in Quercus. Taxon 24:45-50.

Dickson, R.E., and P.T. Tomlinson. 1996. Oak growth, development and carbon metabolism in response to water stress. Annales Des Sciences Forestieres 53:181-196.

Drunasky, D., and D.K. Struve. 2005. Quercus macrocarpa and $Q$. prinus physiological and morphological responses to drought stress and their potential for urban forestry. Urban Forestry and Urban Greening 4:13-22.

Farmer, R.E. Jr. 1979. Comparative analysis of 1st-year growth in six deciduous tree species. Canadian Journal of Forest Research 10:35-41.

Farmer, R.E. Jr., M.A. Barnhill, and J.C. Rennie. 1981. Variation in 10-year growth of northern red oak from provenances in the Tennessee valley, pp. 100-115. In Proceedings of the North Center Tree Improvement Conference, Madison, WI.

Fowells H.A. 1975. Silvics of Forest Trees of the United States. USDA Forest Service Agriculture Handbook No. 271.

Gonzalez, R.A., and D.K. Struve. 1992. A computercontrolled drip irrigation system for container plant production. HortTechnology 2:402-407.

Guttman, S.I., and L.A. Weigt. 1988. Electrophoretic evidence of relationships among Quercus (oaks) of eastern North America. Canadian Journal of Botany 67:339-351.

Hanson, P.J., R.E. Dickson, J.G. Isebrands, T.R. Crow, and R.K. Dixon. 1986. A morphological index of Quercus seedling ontogeny for use in studies of physiology and growth. Tree Physiology 2:273-281.

Harlow, W.M., E.S. Harrar, and F.M. White. 1979. Textbook of Dendrology. 6th Ed. McGraw-Hill, New York, NY.

Hokanson, S.C., J.G. Isebrands, R.J. Jensen, and J.F. Hancock. 1993. Isozyme variation in oaks of the Apostle Islands in Wisconsin: genetic structure and levels of inbreeding in Quercus rubra and Q. ellipsoidalis (Fagaceae). American Journal of Botany 80:1349-1357.

Houston, D.B. 1983. Stand and seed source variation in peroxidases isozymes of Quercus rubra L. Silvae Genetica 32:59-63. 
Jensen, R.J. 1977. A preliminary numerical analysis of the red oak complex in Michigan and Wisconsin. Taxon 26: 399-407.

Jensen, R.J., R. DePiero, and B.K. Smith. 1984. Vegetative characters, population variation and the hybrid origin of Quercus ellipsoidalis. American Midland Naturalist 111: 364-370.

Jensen, R.J., and W.H. Eshbaugh. 1976. Numerical taxonomic studies of hybridization in Quercus. I: Populations of restricted areal distribution and low taxonomic diversity. Systematic Botany 1:1-10.

Kriebel, H.B., W.T. Bagley, E.J. Deneke, R.W. Funsch, P. Roth, J.J. Jokela, C. Merritt, J.W. Wright, and R.D. Williams. 1977. Geographic variation in Quercus rubra in north central United States plantations. Silvae Genetica 25:118-122.

Kriebel, H.B., C. Merritt, and T. Stadt. 1988. Genetics of growth rate in Quercus rubra: provenance and family effects by the early third decade in the North Central USA. Silvae Genetica 37:193-198.

Long, T.J., and R.H. Jones. 1996. Seedling growth strategies and seed size effects in fourteen oak species native to different soil moisture habitats. Trees (Berlin) 11:1-8.

Manos, P.S., and D.E. Fairbrothers. 1987. Allozyme variation in populations of six Northeastern American red oak (Fagaceae:Quercus subg. Erythobalanus). Systematic Botany 12:365-373.

Palmer, E.J. 1948. Hybrid oaks of North America. Journal of the Arnold Arboretum 24:1-49.

Schlarbaum, S.E., and W.T. Bagley. 1981. Intraspecific genetic variation of Quercus rubra L., Northern red oak. Silvae Genetica 30:50-56.

Schwarzmann, J.F., and H.D. Gerhold. 1991. Genetic structure and mating system of northern red oak (Quercus rubra L.) in Pennsylvania. Forest Science 37:1376-1389.

Sork, V.L., S. Huang, and E. Wiener. 1993. Macrogeographic and fine-scale genetic structure in a North American oak species, Quercus rubra L. Annales Des Sciences Forestieres 50(suppl 1):261-270s.

Spetich, M.A., D.C. Dey, P.S. Johnson, and D.L. Graney. 2002. Competitive capacity of Quercus rubra L. planted in Arkansas' Boston mountains. Forest Science 48: 504-517.

Struve, D.K., and S.E. McKeand. 1994. Importance of red oak mother tree to nursery productivity. Journal of Enviornmental Horticulture 12:23-26.

Tomlinson, P.T., R.J. Jensen, and J.F. Hancock. 2000. Do whole tree silvic characters indicate hybridization in red oak (Quercus section Lobatea)? American Midland Naturalist 143:154-168.

Received for publication September 15, 2005, in revised form May 15, 2006. Manuscript No. 05-28. The Ohio Agricultural Re- search and Development Center, The Ohio State University, Columbus, $\mathrm{OH}$.

Daniel K. Struve (corresponding author)

Professor

Department of Horticulture and Crop Science

The Ohio State University

2001 Fyffe Ct.

Columbus, OH 43210, U.S.

Struve.1@osu.edu

Petra Sternberg

Graduate Student

Department of Horticulture and Crop Science

The Ohio State University

2001 Fyffe Ct.

Columbus, OH 43210, U.S.

Nick Drunasky

Former Graduate Research Assistant

Department of Horticulture and Crop Science

The Ohio State University

2001 Fyffe Ct.

Columbus, OH 43210, U.S.

Kurt Bresko

Research Associate

Department of Horticulture and Crop Science

The Ohio State University

2001 Fyffe Ct.

Columbus, OH 43210, U.S.

Rico Gonzalez

Former Graduate Research Assistant

Department of Horticulture and Crop Science

The Ohio State University

2001 Fyffe Ct.

Columbus, $\mathrm{OH} 43210$, U.S.

Zusammenfassung. In einer Serie von 4 Experimenten wurden bei 6 amerikanischen Eichenarten der Sämlingaufwuchs und der Wasserverbrauch untersucht, um den inter und intra-artenspezifischen Wasserverbrauch zu bestimmen. Die an trockene Standorte adaptieren Arten $Q$. prinus, $Q$. velutina hatten ein langsameres Wachstum (Höhe und Trockengewichtakkumulation und niedriges Trieb-Wurzel-Verhältnis) als die an mittlere Standorte adaptierten Arten (Q. macrocarpus, Q. palustris, Q. rubra und Q. shumardii). Die prinzipielle Komponentenanalyse (eine statistische Technik zur Identifikation von korrelierten Variablen) benutzte 11 Variablen und kam in dem ersten Durchgang zu dem Ergebnis, dass der Wasserverbrauch der Sämlinge positiv mit den Wachstumsfaktoren (größere Sämlinge tendieren zu größeren Trockengewichten, größeren Blatt- und Wurzelflächen und verbrauchen mehr Wasser 
als kleinere Sämlinge, die zu kleineren Trockengewichten und kleineren Blatt- und Wurzelflächen tendieren) verbunden ist. Doch im dritten Experiment waren die Wachstumsfaktoren bei $Q$. prinus negativ korreliert mit dem Wasserverbrauch. Große $Q$. prinus Sämlinge tendierten zu weniger Wasserverbrauch als kürzere Sämlinge. Doch die anderen Messungen des Wasserverbrauchs ( $\mathrm{g}$ Wasser $\mathrm{cm}^{-1}$ Höhe und $\mathrm{cm}^{-2}$ Blatt- und Wurzelfläche) waren negativ beim ersten Durchlauf. Die Korrelationen zwischen der Sämlingshöhe und dem Wasserverbrauch waren signifikant und positiv aber groß unter den verschiedenen Arten und innerhalb der Familien wurden Differenzen bei der Höhe in Vergleich zum Wasserverbrauch ( $g$ Wasser $\mathrm{cm}^{-1}$ Höhe) gefunden. Bei der Erhebung des an die Höhe angepassten Wasserverbrauchs konnten effiziente und uneffiziente Sämlinge identifiziert werden. Sämlinge mit uneffizientem Wasserverbrauch waren kürzer und hatten einen höheren Wasserverbrauch pro $\mathrm{cm}^{-1}$ Höhe. Sämlinge mit uneffizientem Wasserverbrauch wurden beschrieben als an trockene Standorte adaptierte Pflanzen, während große Sämlinge einen mittleren Wasserverbrauch zeigten. Potentiell kann der an die Höhe angepasste Wasserverbrauch als eine Methode genutzt werden, um individuelle Eichensämlinge, die besser an stressreiche Standorte in der Stadt zu adaptieren sind, zu selektieren.

Resumen. Se estudió el crecimiento y el uso del agua de brinzales de seis especies de encinos norte americanos en una serie de cuatro experimentos para determinar las características de uso del agua intraespecies. Las especies adaptadas a sitios xéricos (Q. prinus (L.) y Q. velutina (Lamb.)) tuvieron más bajo crecimiento (acumulación de altura y peso seco, más baja relación brote:raíz) que las especies adaptadas a sitios mésicos (Quercus macrocarpus (Michx.); Q. pal ustris (Muenchh.), Q. rubra (L); y Q. shumardii (Buck!)).El Análisis de Componentes Principales (una técnica estadística usada para identificar variables correlacionadas), usando 11 variables, encontró que el uso del agua por los brinzales se cargó positivamente con los factores de crecimiento (los brinzales más altos tendieron a tener mayores pesos secos, y mayores áreas foliares y radiculares y usaron más agua que los brinzales más pequeños, los cuales tendieron a tener más bajos pesos secos y más pequeñas áreas foliares y radiculares), en el primer Componente Principal. Sin embargo, en el tercer experimento, los factores de crecimiento se cargaron negativamente con el uso del agua para Q. prinus. Los brinzales altos de Q. prinus tendieron a usar menos agua que los brinzales chicos. Sin embargo,

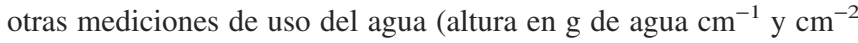
de área foliar y radicular) cargaron negativamente en el primer Componente Principal. La correlación entre las alturas de los brinzales y el agua usada fue significativa y positiva, pero mayor dentro de especies y familias. Mediante el ploteo de uso del agua contra altura de los brinzales, pudo ser identificado un uso eficiente e ineficiente del agua por los brinzales. El uso ineficiente del agua por los brinzales fue más corto y tuvo altura más alta en $\mathrm{cm}^{-1}$ que el uso eficiente. El uso ineficiente del agua fue descrito como hábito de agua xérica mientras que los brinzales altos tuvieron un hábito de uso mésico. Potencialmente, el uso del agua puede ser utilizado como un método para seleccionar encinos individuales mejor adaptados a los sitios críticos en plantaciones urbanas. 